OPEN ACCESS

Edited by:

Tomomi Toubai,

Yamagata University, Japan

Reviewed by:

Timothy Devos,

University Hospitals Leuven, Belgium

Ryotaro Nakamura,

City of Hope National Medical Center. United States

*Correspondence:

Makoto Murata

mmurata@med.nagoya-u.ac.jp

Specialty section:

This article was submitted to Alloimmunity and Transplantation,

a section of the journal

Frontiers in Immunology

Received: 13 June 2021

Accepted: 29 July 2021

Published: 19 August 2021

Citation:

Murata M and Teshima T (2021) Treatment of Steroid-Refractory Acute

Graft-Versus-Host Disease Using

Commercial Mesenchymal Stem Cell Products.

Front. Immunol. 12:724380. doi: 10.3389/fimmu.2021.724380

\section{Treatment of Steroid-Refractory Acute Graft-Versus-Host Disease Using Commercial Mesenchymal Stem Cell Products}

\author{
Makoto Murata $^{1 *}$ and Takanori Teshima ${ }^{2}$ \\ ${ }^{1}$ Department of Hematology and Oncology, Nagoya University Graduate School of Medicine, Nagoya, Japan, \\ 2 Department of Hematology, Hokkaido University Faculty of Medicine, Sapporo, Japan
}

Acute graft-versus-host disease (GVHD) is a life-threatening complication that can develop after allogeneic hematopoietic stem cell transplantation. In particular, the prognosis of patients with steroid-refractory acute GVHD is extremely poor. Ryoncil ${ }^{\mathrm{TM}}$ (remestemcel-L), a human bone marrow-derived mesenchymal stem cell (MSC) product, failed to show superiority over placebo in patients with steroid-refractory acute GVHD, but it was approved for use in pediatric patients in Canada and New Zealand based on the results of a subgroup analysis. Temcell ${ }^{\circledR}$, an equivalent manufactured MSC product to remestemcel-L, was approved in Japan based on small single-arm studies by using a regulation for regenerative medicine in 2016. The efficacy of Temcell was evaluated in 381 consecutive patients treated with Temcell during the initial 3 years after its approval. Interestingly, its real-world efficacy was found to be equivalent to that observed in a prospective study of remestemcel-L with strict eligibility criteria. In this article, the potential of MSC therapy in the treatment of acute GVHD is discussed. A meticulous comparison of studies of remestemcel- $L$ and Temcell, remestemcel-L/Temcell and ruxolitinib, and remestemcel-L/Temcell and thymoglobulin showed that the precise position of remestemcel-L/Temcell therapy in the treatment of acute GVHD remains to be determined.

Keywords: graft-versus-host disease (GVHD), mesenchymal stem cell (MSC), steroid, ruxolitinib, thymoglobulin

\section{INTRODUCTION}

Acute graft-versus-host disease (GVHD) is a life-threatening complication that can develop after allogeneic hematopoietic stem cell transplantation (HSCT) $(1,2)$. Systemic corticosteroid is a standard first-line treatment, but the response rate ranges from $40 \%$ to $60 \%(3,4)$. Many agents have been evaluated as second-line treatment for acute $\operatorname{GVHD}(5,6)$. However, no consensus has been reached regarding the optimal approach for the management of steroid-refractory acute GVHD (SR-aGVHD) (7). A recent, randomized, phase 3 study comparing ruxolitinib and control (nine treatment options) for SR-aGVHD demonstrated a higher overall response (OR), defined as complete response (CR) and partial response (PR), in the ruxolitinib group (8). However, the study failed to demonstrate a significant advantage of using ruxolitinib in terms of overall survival 
(OS) or non-relapse mortality (NRM). Another recent, randomized, phase 3 trial comparing inolimomab and control (antithymocyte globulin) also demonstrated no significant advantage using inolimomab in terms of OS (9). Thus, no second-line treatment has been proven to improve survival in patients with SR-aGVHD.

Mesenchymal stem cells (MSCs) have been extensively studied as a treatment for SR-aGVHD (10). Efficacy of the commercial MSC product remestemcel-L (Ryoncil ${ }^{\mathrm{TM}}$, Mesoblast, Ltd, Melbourne, Australia; formerly Prochymal ${ }^{\circledR}$, Osiris Therapeutics, Columbia, MD, USA) was evaluated in a randomized, phase 3 trial comparing the administration of remestemcel-L and of placebo in conjunction with another second-line therapy (11). Unfortunately, the study failed to meet its primary endpoint of durable CR and the secondary endpoint of the OR rate. Thus, despite a number of reports of positive outcomes of MSC therapy, unambiguous evidence of efficacy from randomized studies is still lacking (12).

However, the post hoc analyses of the randomized trial demonstrated that the pediatric patients, as well as the patients with liver involvement, in the remestemcel-L group had a significantly higher OR rate than those in the placebo group (11). In Japan, Temcell ${ }^{\circledR}$ (JCR Pharmaceuticals Co. Ltd, Ashiya, Japan) was approved based on the results of small single-arm studies as "regenerative medicine" via a new Japanese initiative on stem cell therapies, which requires the results of additional clinical trials to confirm safety and to predict likely efficacy, in 2016. Temcell, which has no generic name, is the equivalent manufactured MSC product to remestemcel-L, derived from unrelated adult bone marrow. We recently reported the outcomes of 381 consecutive patients who were treated with Temcell during the initial 3 years after its approval (13). Interestingly, the treatment outcomes of Temcell in the realworld setting achieved an efficacy equivalent to that obtained in a prospective study of remestemcel-L. The multivariate analyses identified some factors to predict a higher OR rate and lower NRM after Temcell therapy in patients with SR-aGVHD.

This Mini Review article will discuss the potential of MSC therapy in the treatment of acute GVHD based mainly on data from the studies of a large number of patients receiving remestemcel-L or Temcell.

\section{A BRIEF REVIEW OF MSC THERAPY FOR ACUTE GVHD}

MSCs, which are alternatively defined as mesenchymal "stromal" cells, can be isolated and expanded from various tissues including bone marrow (14), umbilical cord (15), placenta (16), adipose tissue (17), and dental pulp (18). In the bone marrow, MSCs at different stages of maturation form the hematopoietic stem cell (HSC) niche, which play an important role in the maintenance and renewal of HSCs (19). These properties may contribute to facilitating the engraftment of transplanted HSCs, and therefore co-transplantation of MSCs with HSCs has been widely studied to promote engraftment in autologous and allogeneic HSCT (20-34). On the other hand, MSCs interact with the innate and adaptive immune systems via the direct cell-to-cell contact and the release of soluble factors, resulting in the regulation of immune activities (19). These properties may contribute to treating immune-mediated diseases, and therefore administration of MSCs has been widely studied to treat acute and chronic GVHD $(11,13,35-$ 64). A recent mouse study suggested that MSCs promoted the proliferation of innate lymphoid cells and their production of interleukin-22 (65), which stimulate proliferation and differentiation of intestinal stem cells to regenerate the damaged tissue (66). However, this remains to be proved clinically. Another recent study raised an alternative hypothesis that an apoptosis of infused MSCs by recipient cytotoxic cells may contribute to MSC-induced immunosuppression (67).

MSCs were initially manufactured at each transplant hospital or factory by using various cell sources and culture methods, resulting in heterogeneity of MSCs (68). Thereafter, a commercial MSC product, remestemcel-L (Prochymal, currently Ryoncil), was developed in the United States (38). In Europe, a clinical-grade MSC product, called MSC-Frankfurt am Main, can now be used in clinical practice across several European countries $(46,52)$. According to the literature, more than 1400 patients have received MSCs as treatment of acute GVHD in the world $(11,13,35-59)$. The numbers of acute GVHD patients treated with MSCs by year of publication are shown in Figure 1. Interestingly, there is a trend that OR rates were higher in previous studies than in recent larger studies. For all of these reported cases, the overall OR rate was 63\%. Overall, MSC therapy is well tolerated. Infusion-related reactions were observed in $1.8 \%$ of patients who received remestemcel- $\mathrm{L}$, less than that in patients who received placebo (2.5\%) (11). No ectopic tissue formation has been reported. Although one retrospective study found a significant increase of pneumoniarelated death with MSC therapy than without MSC therapy (59), another retrospective study demonstrated no difference in the risks of infections and relapse between MSC and non-MSC therapies (58). There were no differences in the rates of infection and relapse between the remestemcel-L and placebo groups in a randomized study (11).

In this review, we particularly focus on three major studies of commercial MSC products, including large number of patients $(11,13,56)$, in order to avoid heterogeneity of MSC product.

\section{MSC THERAPY WITH REMESTEMCEL-L FOR ACUTE GVHD}

A randomized, phase 3 trial of remestemcel-L $v$ s. placebo added to another second-line therapy according to institutional standards in patients with SR-aGVHD was conducted (11). The main results of the study are summarized in Table 1. Of the 260 randomized patients, 163 received at least one infusion of remestemcel-L, and 81 received at least one infusion of placebo. Remestemcel-L therapy did not meet the primary endpoint of greater durable CR for at least 28 days within the first 100 days 


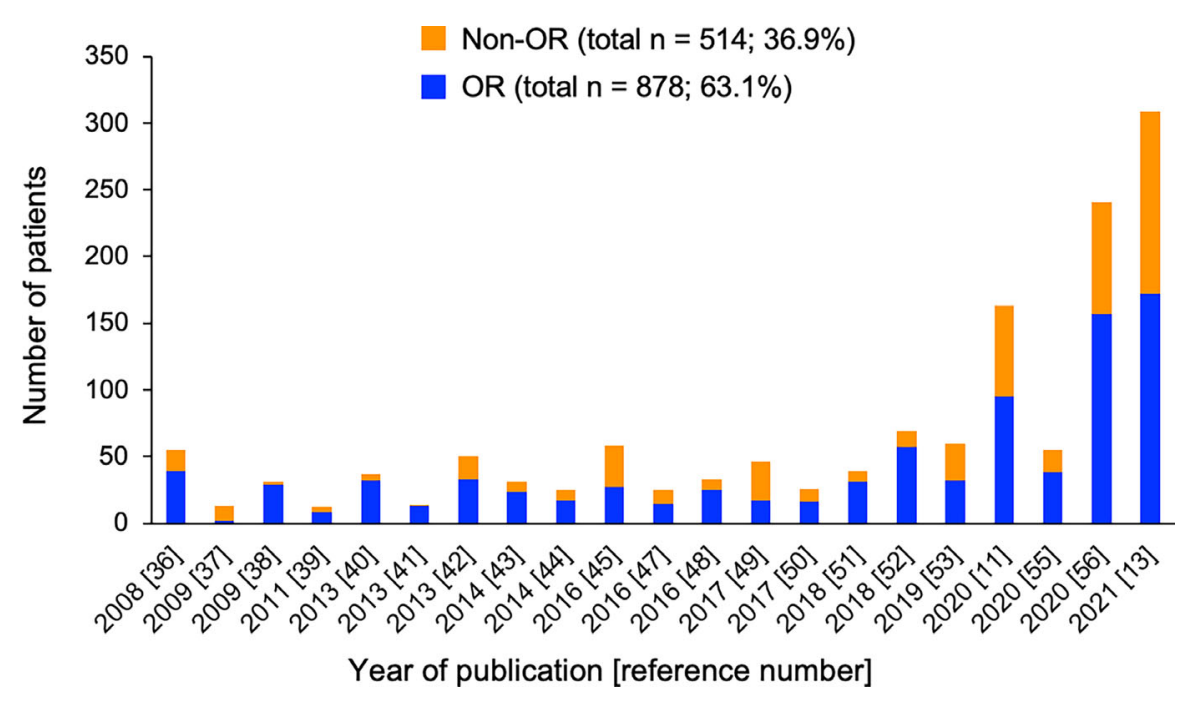

FIGURE 1 | Number of patients with (blue) and without (orange) overall response (OR) in each study of MSC therapy for acute GVHD. Total numbers and percentages of patients with or without OR as the sum of all reported cases are provided.

after enrollment (35\% vs. $30 \% ; P=0.42)$. The proportions of patients achieving OR on day $28(58 \%$ vs. 54\%; $P=0.59)$ and OS on day 180 ( $34 \%$ vs. $42 \% ; P=0.60)$ were not different between the remestemcel-L and placebo groups.

A single-arm expanded access treatment with remestemcel-L in 241 patients under the age of 18 years with acute GVHD resistant to multiple immunosuppressive therapies was conducted (56). The main results of the study are summarized in Table 1. Despite the fact that $50 \%$ of patients had grade D acute GVHD (70), and 79\% were classified as high-risk acute GVHD (71), 65\% of patients achieved OR on day 28. The achievement of OR on day 28 was associated with higher OS on day 100: $82 \%$ in patients with OR and $39 \%$ without OR $(P<$ $0.0001, \log$-rank test).

\section{MSC THERAPY WITH TEMCELL FOR ACUTE GVHD}

More recently, real-world outcomes for 381 patients who received Temcell as a health insurance-covered treatment for acute GVHD were reported from Japan (13). The main results of the study are summarized in Table 1. Of the 309 patients, $56 \%$ achieved OR on day 28. Of the 153 patients who received Temcell as a second-line therapy following first-line steroid therapy for classic acute GVHD, 61\% achieved OR on day 28. Thus, the treatment of acute GVHD with Temcell covered by health insurance in Japan achieved an efficacy equivalent to that obtained in prospective studies of remestemcel-L with strict eligibility criteria.

On multivariate analysis, liver involvement of acute GVHD and longer duration from first-line steroid therapy to second-line MSC therapy ( $\geq 14$ days $v s$. $<14$ days) were associated with a lower OR rate. Older patient ( 18 to 49 years and $\geq 50$ years $v s .<18$ years), higher grade of GVHD (III and IV $v s . \leq$ II), higher number of GVHD therapies before MSC therapy ( $\geq 2 v s . \leq 1)$, and nonachievement of OR on day 28 were associated with a higher NRM. OS was significantly higher in patients with an OR on day 28 than in those without an OR.

\section{IS THE EFFICACY OF REMESTEMCEL-L/ TEMCELL GREATER IN PEDIATRIC PATIENTS?}

A post hoc analysis of a randomized study demonstrated that the OR rate was significantly higher in the pediatric patients receiving remestemcel- $\mathrm{L}$ than in the pediatric patients receiving placebo (64\% vs. $23 \% ; P=0.05)$ (11). However, it should be noted that only 13 pediatric patients were allocated to the placebo group, and only three $(23 \%)$ of them achieved OR, in sharp contrast to the OR rate of $60 \%$ in 68 adult patients allocated to the placebo group (11). In the retrospective study of Temcell, there was no significant difference in OR rates among three age groups ( $<18,18$ to 49 , and $\geq 50$ years) (13). Thus, there is not enough evidence to prove greater efficacy of remestemcel$\mathrm{L} /$ Temcell in pediatric patients compared with adult patients.

\section{IS REMESTEMCEL-L/TEMCELL EFFECTIVE FOR LIVER ACUTE GVHD?}

A post hoc analysis of a randomized study demonstrated that the OR rate in patients with liver acute GVHD was significantly higher in the remestemcel-L group than in the placebo group (55\% vs. 26\%; $P=0.05$ ) (11). OR rates in the remestemcel-L group were almost equal among the patients with liver, skin, and gut acute GVHD (55\%, 58\%, and 57\%, respectively) (11). 


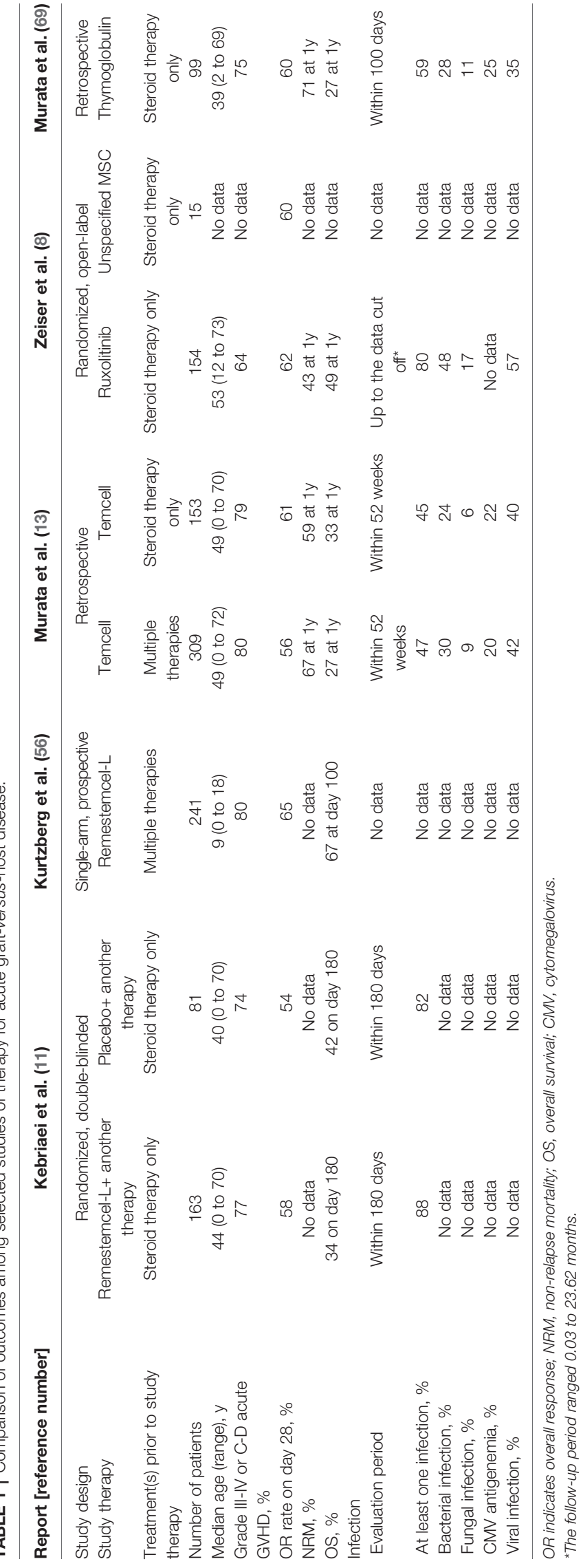

Similar results were obtained in a single-arm prospective study of remestemcel-L for pediatric patients; OR rates in the pediatric patients with liver, skin, and gut acute GVHD were $62 \%, 68 \%$, and $65 \%$, respectively (56).

On the other hand, a significantly lower OR rate in the patients with liver involvement of acute GVHD was reported in a retrospective study of Temcell; the OR rate in patients with liver acute GVHD was 36\%, whereas OR rates in patients with skin or gut acute GVHD were $64 \%$ and $57 \%$, respectively (13). Other immunosuppressants, such as ruxolitinib, antithymocyte globulin, and infliximab, are also reported to be less effective for liver acute GVHD than for skin or gut acute GVHD (69, 72-74). In the current situation where there is no fully effective treatment for liver acute GVHD, remestemcel-L/Temcell is an option for liver acute GVHD, but the efficacy of MSC therapy for liver acute GVHD remains unclear.

\section{WHEN IS THE BEST TIME TO INITIATE REMESTEMCEL-L/TEMCELL THERAPY?}

In a retrospective study of Temcell, multivariate analysis of all evaluable patients demonstrated a lower NRM in patients with no or one GVHD therapy before Temcell therapy compared with two or more GVHD therapies (odds ratio, $0.65 ; 95 \%$ confidence interval, 0.47 to 0.91 ) (13). Multivariate analysis of patients who received second-line Temcell therapy following first-line steroid therapy demonstrated a higher OR rate in patients with $<14$ days than $\geq$ 14 days between first-line steroid therapy and second-line Temcell therapy (odds ratio, 2.27; 95\% confidence interval, 1.09 to 4.76 ) (13).

In contrast, a single-arm prospective study of remestemcel-L for pediatric patients demonstrated no significant difference in the OR rate among the three groups of durations between firstline therapy and remestemcel-L therapy (74\% for $\leq 14$ days, $56 \%$ for 15 to 28 days, and $67 \%$ for $\geq 28$ days). Thus, although it is possible that early initiation of remestemcel-L/Temcell therapy may have an advantage in terms of a higher response rate and/or lower NRM, further analysis of a larger cohort is required to provide an accurate answer to this question.

\section{HOW MANY INFUSIONS OF REMESTEMCEL-L/TEMCELL ARE REQUIRED TO OBTAIN A RESPONSE?}

Remestemcel-L/Temcell at a dose of $2 \times 10^{6}$ cells $/ \mathrm{kg}$ was infused twice weekly for 4 consecutive weeks with additional infusion once weekly for a further 4 weeks in prospective studies $(11,41$, $47,55,56)$. Analysis of real-world data of Temcell in Japan demonstrated that $61 \%$ of patients received $\leq 8$ infusions, and $39 \%$ received 9 to 12 infusions (13). In patients who achieved OR by Temcell therapy, $50 \%$ and $90 \%$ achieved it by day 15 and day 28 , respectively. These data suggest that less than 8 infusions may be sufficient in most patients, whereas more than 8 infusions are required only in a small population of patients. 
On the other hand, $10 \%$ of the patients who achieved OR by day 28 with 8 infusions of Temcell experienced GVHD relapse as of day 90. Taken together, the administration schedule of remestemcel-L/Temcell therapy has not been optimized, or it has to be individually optimized.

\section{WHICH IS MORE EFFECTIVE FOR ACUTE GVHD, RUXOLITINIB OR REMESTEMCEL-L/TEMCELL?}

It must be stated again that ruxolitinib is the only drug that has been proven to be significantly more effective than control (nine therapies) in a randomized, open-label trial (8). Ruxolitinib inhibits Janus kinase $1 / 2$ signaling, resulting in the blockade of multiple cytokines, dendritic cell activation, and neutrophil activation (75). The main results of this study (8) are summarized in Table 1 . The patients assigned to the ruxolitinib therapy $(n=154)$ achieved an OR rate of $62 \%$ on day 28, which was significantly higher than that (39\%) in 155 patients receiving control therapy $(P<0.001)$. MSC was one of nine options for patients assigned to the control therapy; 15 patients received MSCs and $9(60 \%)$ of them achieved OR on day 28 (Table 1). Although this study was not designed to compare ruxolitinib and each control treatment, OR rates in the patients receiving ruxolitinib and MSCs were similar (8). This has been the only prospective comparison of efficacy between ruxolitinib and MSC therapies for treatment of SR-aGVHD.

Unfortunately, NRM in the patients receiving MSCs as a control therapy was not analyzed in the randomized trial (8). Although NRM cannot be directly compared between prospective and retrospective studies, NRM at 1 year in patients with ruxolitinib therapy in a prospective study (8) was much lower than that in patients with Temcell therapy in a retrospective study (13) (43\% vs. 59\%). Future comparative studies between ruxolitinib and MSC therapies, in which the primary endpoint is defined as NRM or OS, but not the response rate, are of interest.

The most common adverse events of ruxolitinib therapy have been reported to be thrombocytopenia, anemia, and cytomegalovirus infection (8). The incidences of each infection after Temcell therapy (13) might be lower than those after ruxolitinib therapy (8) (Table 1). However, due to a difference in the evaluation period and a lack of detailed information about clinical course, it is not possible to conclude that Temcell therapy is less likely to cause infection compared with ruxolitinib therapy.

\section{WHICH IS MORE EFFECTIVE FOR ACUTE GVHD, ANTITHYMOCYTE GLOBULIN OR REMESTEMCEL-L/TEMCELL?}

Antithymocyte globulin affects not only T cells, but also B cells, dendritic cells, regulatory $\mathrm{T}$ cells, and natural killer $\mathrm{T}$ cells, resulting in its diverse effects on the immune system (76).
The major adverse events of antithymocyte globulin therapy are infusion reaction and viral and fungal infections (77). There has been no prospective study comparing antithymocyte globulin and MSC therapies for acute GVHD treatment. However, the outcome of 99 patients who received thymoglobulin as a secondline treatment for SR-aGVHD (69) was comparable to that of 153 patients who received Temcell as a second-line treatment for SR-aGVHD (13). Both retrospective studies included consecutive patients during the initial three or four years after their health insurance approval in Japan.

The main results of the thymoglobulin study are summarized in Table 1. The OR rate on day 28 in the thymoglobulin study (60\%) was equal to that of Temcell therapy (61\%). However, NRM at 1 year was higher with thymoglobulin therapy than with Temcell therapy (71\% vs. 59\%). This difference resulted from neither patient age nor severity of GVHD, because the median age was not higher, but rather lower in the thymoglobulin study than in the Temcell study (39vs. 49 years, respectively), and the proportion of grade III to IV acute GVHD was slightly lower in the thymoglobulin study than in the Temcell study (75\% vs. $79 \%$, respectively). Of note, the incidence of any additional infection within the first 100 days after the start of thymoglobulin therapy was $59 \%$, whereas that within 52 weeks after Temcell therapy was $45 \%$ (Table 1), suggesting that Temcell therapy may have an advantage of a lower NRM associated with infectious complications compared with thymoglobulin therapy. Further analysis with detailed information, such as severity and therapeutic response of each infection, is required.

\section{HAS THERE BEEN A STUDY TO COMPARE MSCS AND OTHER THERAPIES FOR ACUTE GVHD?}

There have been no other prospective or retrospective studies to compare the efficacy of MSCs and other immunosuppressants in the treatment of acute GVHD.

\section{CONCLUSION}

It is known that the incidence of severe acute GVHD is lower in Japanese than Caucasian patients (78), but the outcome of SRaGVHD seems to be equally poor (4). Thus, effective second-line treatments for SR-aGVHD are an unmet need. Ruxolitinib is widely used as an acute GVHD treatment in the United States and Europe, but the use of MSCs has not been approved as a health insurance treatment in those countries. In contrast, Temcell is widely used in Japan, but ruxolitinib remains under review. Thus, it is currently impossible to compare the efficacy of remestemcel-L/Temcell and ruxolitinib in a real-world setting. As described in an earlier section, there has been a randomized, prospective study of remestemcel-L and placebo (11). The correct interpretation of the study is that the addition of 
remestemcel-L to another second-line therapy was not superior to a second-line therapy without remestemcel-L. In other words, the efficacy of remestemcel-L alone has not been prospectively compared with other immunosuppressive drugs in the treatment of acute GVHD.

In conclusion, the appropriate use of remestemcel-L/Temcell for acute GVHD remains to be determined. Future study is needed to establish more precisely the position of remestemcel$\mathrm{L} /$ Temcell in the treatment of acute GVHD.

\section{AUTHOR CONTRIBUTIONS}

MM designed the review and wrote the manuscript, and TT wrote the manuscript and supervised the process. All authors contributed to the article and approved the submitted version.

\section{REFERENCES}

1. Zeiser R, Blazar BR. Acute Graft-Versus-Host Disease - Biologic Process, Prevention, and Therapy. N Engl J Med (2017) 377(22):2167-79. doi: 10.1056/ NEJMra1609337

2. Toubai T, Magenau J. Immunopathology and Biology-Based Treatment of Steroid-Refractory Graft-Versus-Host Disease. Blood (2020) 136(4):429-40. doi: 10.1182/blood.2019000953

3. MacMillan ML, Weisdorf DJ, Wagner JE, DeFor TE, Burns LJ, Ramsay NK, et al. Response of 443 Patients to Steroids as Primary Therapy for Acute Graft-VersusHost Disease: Comparison of Grading Systems. Biol Blood Marrow Transplant (2002) 8(7):387-94. doi: 10.1053/bbmt.2002.v8.pm12171485

4. Murata M, Nakasone H, Kanda J, Nakane T, Furukawa T, Fukuda T, et al. Clinical Factors Predicting the Response of Acute Graft-Versus-Host Disease to Corticosteroid Therapy: An Analysis From the GVHD Working Group of the Japan Society for Hematopoietic Cell Transplantation. Biol Blood Marrow Transplant (2013) 19(8):1183-9. doi: 10.1016/j.bbmt.2013.05.003

5. Martin PJ, Rizzo JD, Wingard JR, Ballen K, Curtin PT, Cutler C, et al. Firstand Second-Line Systemic Treatment of Acute Graft-Versus-Host Disease: Recommendations of the American Society of Blood and Marrow Transplantation. Biol Blood Marrow Transplant (2012) 18(8):1150-63. doi: 10.1016/j.bbmt.2012.04.005

6. Murata M. Prophylactic and Therapeutic Treatment of Graft-Versus-Host Disease in Japan. Int J Hematol (2015) 101(5):467-86. doi: 10.1007/s12185015-1784-2

7. Martin PJ. How I Treat Steroid-Refractory Acute Graft-Versus-Host Disease. Blood (2020) 135(19):1630-8. doi: 10.1182/blood.2019000960

8. Zeiser R, von Bubnoff N, Butler J, Mohty M, Niederwieser D, Or R, et al. Ruxolitinib for Glucocorticoid-Refractory Acute Graft-Versus-Host Disease. N Engl J Med (2020) 382(19):1800-10. doi: 10.1056/NEJMoa1917635

9. Socié G, Vigouroux S, Yakoub-Agha I, Bay JO, Fürst S, Bilger K, et al. A Phase 3 Randomized Trial Comparing Inolimomab vs Usual Care in SteroidResistant Acute GVHD. Blood (2017) 129:643-9. doi: 10.1182/blood-201609-738625

10. Burnham AJ, Daley-Bauer LP, Horwitz EM. Mesenchymal Stromal Cells in Hematopoietic Cell Transplantation. Blood Adv (2020) 4(22):5877-87. doi: 10.1182/bloodadvances.2020002646

11. Kebriaei P, Hayes J, Daly A, Uberti J, Marks DI, Soiffer R, et al. A Phase 3 Randomized Study of Remestemcel-L Versus Placebo Added to Second-Line Therapy in Patients With Steroid-Refractory Acute Graft-Versus-Host Disease. Biol Blood Marrow Transplant (2020) 26(5):835-44. doi: 10.1016/ j.bbmt.2019.08.029

12. Fisher SA, Cutler A, Doree C, Brunskill SJ, Stanworth SJ, Navarrete C, et al. Mesenchymal Stromal Cells as Treatment or Prophylaxis for Acute or Chronic Graft-Versus-Host Disease in Haematopoietic Stem Cell Transplant (HSCT)

\section{FUNDING}

This work was supported in part by a Practical Research Project for Allergic Diseases and Immunology (Research on Technology of Medical Transplantation) (JP21ek0510032 to MM) from the Japan Agency for Medical Research and Development (AMED) and by a Grant-in-Aid for Scientific Research (21K08387 to MM) from the Japan Society for the Promotion of Science (JSPS).

\section{ACKNOWLEDGMENTS}

The authors would like to thank the members of the GVHD working group of the Japanese Society for Transplantation and Cellular Therapy, all the staff of the Japanese Data Center for Hematopoietic Cell Transplantation, and all the physicians, nurses, and other staff at each transplant hospital in Japan.

Recipients With a Haematological Condition. Cochrane Database Syst Rev (2019) 1(1):CD009768. doi: 10.1002/14651858.CD009768.pub2

13. Murata M, Terakura S, Wake A, Miyao K, Ikegame K, Uchida N, et al. OffThe-Shelf Bone Marrow-Derived Mesenchymal Stem Cell Treatment for Acute Graft-Versus-Host Disease: Real-World Evidence. Bone Marrow Transplant (2021). doi: 10.1038/s41409-021-01304-y

14. Kopen GC, Prockop DJ, Phinney DG. Marrow Stromal Cells Migrate Throughout Forebrain and Cerebellum, and They Differentiate Into Astrocytes After Injection Into Neonatal Mouse Brains. Proc Natl Acad Sci USA (1999) 96(19):10711-6. doi: 10.1073/pnas.96.19.10711

15. Erices A, Conget P, Minguell JJ. Mesenchymal Progenitor Cells in Human Umbilical Cord Blood. Br J Haematol (2000) 109(1):235-42. doi: 10.1046/ j.1365-2141.2000.01986.x

16. In 't Anker PS, Scherjon SA, Kleijburg-van der Keur C, de Groot-Swings GM, Claas FH, Fibbe WE, et al. Isolation of Mesenchymal Stem Cells of Fetal or Maternal Origin From Human Placenta. Stem Cells (2004) 22(7):1338-45. doi: 10.1634/stemcells.2004-0058

17. Zannettino AC, Paton S, Arthur A, Khor F, Itescu S, Gimble JM, et al. Multipotential Human Adipose-Derived Stromal Stem Cells Exhibit a Perivascular Phenotype In Vitro and In Vivo. J Cell Physiol (2008) 214 (2):413-21. doi: 10.1002/jcp.21210

18. Gronthos S, Mankani M, Brahim J, Robey PG, Shi S. Postnatal Human Dental Pulp Stem Cells (DPSCs) In Vitro and In Vivo. Proc Natl Acad Sci USA (2000) 97(25):13625-30. doi: 10.1073/pnas.240309797

19. Uccelli A, Moretta L, Pistoia V. Mesenchymal Stem Cells in Health and Disease. Nat Rev Immunol (2008) 8(9):726-36. doi: 10.1038/nri2395

20. Koç ON, Gerson SL, Cooper BW, Dyhouse SM, Haynesworth SE, Caplan AI, et al. Rapid Hematopoietic Recovery After Coinfusion of Autologous-Blood Stem Cells and Culture-Expanded Marrow Mesenchymal Stem Cells in Advanced Breast Cancer Patients Receiving High-Dose Chemotherapy. J Clin Oncol (2000) 18(2):307-16. doi: 10.1200/JCO.2000.18.2.307

21. Ball LM, Bernardo ME, Roelofs H, Lankester A, Cometa A, Egeler RM, et al. Cotransplantation of Ex Vivo Expanded Mesenchymal Stem Cells Accelerates Lymphocyte Recovery and may Reduce the Risk of Graft Failure in Haploidentical Hematopoietic Stem-Cell Transplantation. Blood (2007) 110 (7):2764-7. doi: 10.1182/blood-2007-04-087056

22. Macmillan ML, Blazar BR, DeFor TE, Wagner JE. Transplantation of Ex-Vivo Culture-Expanded Parental Haploidentical Mesenchymal Stem Cells to Promote Engraftment in Pediatric Recipients of Unrelated Donor Umbilical Cord Blood: Results of a Phase I-II Clinical Trial. Bone Marrow Transplant (2009) 43(6):447-54. doi: 10.1038/bmt.2008.348

23. Guo M, Sun Z, Sun QY, Han Q, Yu CL, Wang DH, et al. A Modified Haploidentical Nonmyeloablative Transplantation Without T Cell Depletion for High-Risk Acute Leukemia: Successful Engraftment and Mild GVHD. Biol Blood Marrow Transplant (2009) 15(8):930-7. doi: 10.1016/j.bbmt.2009.04.006 
24. Gonzalo-Daganzo R, Regidor C, Martín-Donaire T, Rico MA, Bautista G, Krsnik I, et al. Results of a Pilot Study on the Use of Third-Party Donor Mesenchymal Stromal Cells in Cord Blood Transplantation in Adults. Cytotherapy (2009) 11(3):278-88. doi: 10.1080/14653240902807018

25. Baron F, Lechanteur C, Willems E, Bruck F, Baudoux E, Seidel L, et al. Cotransplantation of Mesenchymal Stem Cells Might Prevent Death From Graft-Versus-Host Disease (GVHD) Without Abrogating Graft-VersusTumor Effects After HLA-Mismatched Allogeneic Transplantation Following Nonmyeloablative Conditioning. Biol Blood Marrow Transplant (2010) 16(6):838-47. doi: 10.1016/j.bbmt.2010.01.011

26. Bernardo ME, Ball LM, Cometa AM, Roelofs H, Zecca M, Avanzini MA, et al. Co-Infusion of Ex Vivo-Expanded, Parental MSCs Prevents Life-Threatening Acute GVHD, But Does Not Reduce the Risk of Graft Failure in Pediatric Patients Undergoing Allogeneic Umbilical Cord Blood Transplantation. Bone Marrow Transplant (2011) 46(2):200-7. doi: 10.1038/bmt.2010.87

27. Liu K, Chen Y, Zeng Y, Xu L, Liu D, Chen H, et al. Coinfusion of Mesenchymal Stromal Cells Facilitates Platelet Recovery Without Increasing Leukemia Recurrence in Haploidentical Hematopoietic Stem Cell Transplantation: A Randomized, Controlled Clinical Study. Stem Cells Dev (2011) 20(10):1679-85. doi: 10.1089/scd.2010.0447

28. Lee SH, Lee MW, Yoo KH, Kim DS, Son MH, Sung KW, et al. CoTransplantation of Third-Party Umbilical Cord Blood-Derived MSCs Promotes Engraftment in Children Undergoing Unrelated Umbilical Cord Blood Transplantation. Bone Marrow Transplant (2013) 48(8):1040-5. doi: 10.1038/bmt.2013.7

29. Wu Y, Wang Z, Cao Y, Xu L, Li X, Liu P, et al. Cotransplantation of Haploidentical Hematopoietic and Umbilical Cord Mesenchymal Stem Cells With a Myeloablative Regimen for Refractory/Relapsed Hematologic Malignancy. Ann Hematol (2013) 92(12):1675-84. doi: 10.1007/s00277-013$1831-0$

30. Wu KH, Sheu JN, Wu HP, Tsai C, Sieber M, Peng CT, et al. Cotransplantation of Umbilical Cord-Derived Mesenchymal Stem Cells Promote Hematopoietic Engraftment in Cord Blood Transplantation: A Pilot Study. Transplantation (2013) 95(5):773-7. doi: 10.1097/TP.0b013e31827a93dd

31. Wu Y, Cao Y, Li X, Xu L, Wang Z, Liu P, et al. Cotransplantation of Haploidentical Hematopoietic and Umbilical Cord Mesenchymal Stem Cells for Severe Aplastic Anemia: Successful Engraftment and Mild GVHD. Stem Cell Res (2014) 12(1):132-8. doi: 10.1016/j.scr.2013.10.001

32. Li XH, Gao CJ, Da WM, Cao YB, Wang ZH, Xu LX, et al. Reduced Intensity Conditioning, Combined Transplantation of Haploidentical Hematopoietic Stem Cells and Mesenchymal Stem Cells in Patients With Severe Aplastic Anemia. PLoS One (2014) 9(3):e89666. doi: 10.1371/journal.pone.0089666

33. Xiong YY, Fan Q, Huang F, Zhang Y, Wang Y, Chen XY, et al. Mesenchymal Stem Cells Versus Mesenchymal Stem Cells Combined With Cord Blood for Engraftment Failure After Autologous Hematopoietic Stem Cell Transplantation: A Pilot Prospective, Open-Label, Randomized Trial. Biol Blood Marrow Transplant (2014) 20(2):236-42. doi: 10.1016/j.bbmt.2013.11.002

34. Goto T, Murata M, Nishida T, Terakura S, Kamoshita S, Ishikawa Y, et al. Phase I Clinical Trial of Intra-Bone Marrow Cotransplantation of Mesenchymal Stem Cells in Cord Blood Transplantation. Stem Cells Transl Med (2021) 10(4):542-53. doi: 10.1002/sctm.20-0381

35. Le Blanc K, Rasmusson I, Sundberg B, Götherström C, Hassan M, Uzunel M, et al. Treatment of Severe Acute Graft-Versus-Host Disease With Third Party Haploidentical Mesenchymal Stem Cells. Lancet (2004) 363(9419):1439-41. doi: 10.1016/S0140-6736(04)16104-7

36. Le Blanc K, Frassoni F, Ball L, Locatelli F, Roelofs H, Lewis I, et al. Mesenchymal Stem Cells for Treatment of Steroid-Resistant, Severe, Acute Graft-Versus-Host Disease: A Phase II Study. Lancet (2008) 371(9624):157986. doi: 10.1016/S0140-6736(08)60690-X

37. von Bonin M, Stölzel F, Goedecke A, Richter K, Wuschek N, Hölig K, et al. Treatment of Refractory Acute GVHD With Third-Party MSC Expanded in Platelet Lysate-Containing Medium. Bone Marrow Transplant (2009) 43 (3):245-51. doi: 10.1038/bmt.2008.316

38. Kebriaei P, Isola L, Bahceci E, Holland K, Rowley S, McGuirk J, et al. Adult Human Mesenchymal Stem Cells Added to Corticosteroid Therapy for the Treatment of Acute Graft-Versus-Host Disease. Biol Blood Marrow Transplant (2009) 15(7):804-11. doi: 10.1016/j.bbmt.2008.03.012
39. Prasad VK, Lucas KG, Kleiner GI, Talano JA, Jacobsohn D, Broadwater G, et al. Efficacy and Safety of Ex Vivo Cultured Adult Human Mesenchymal Stem Cells (Prochymal ${ }^{\mathrm{TM}}$ ) in Pediatric Patients With Severe Refractory Acute Graft-Versus-Host Disease in a Compassionate Use Study. Biol Blood Marrow Transplant (2011) 17(4):534-41. doi: 10.1016/j.bbmt.2010.04.014

40. Ball LM, Bernardo ME, Roelofs H, van Tol MJ, Contoli B, Zwaginga JJ, et al. Multiple Infusions of Mesenchymal Stromal Cells Induce Sustained Remission in Children With Steroid-Refractory, Grade III-IV Acute GraftVersus-Host Disease. Br J Haematol (2013) 163(4):501-9. doi: 10.1111/ bjh. 12545

41. Muroi K, Miyamura K, Ohashi K, Murata M, Eto T, Kobayashi N, et al. Unrelated Allogeneic Bone Marrow-Derived Mesenchymal Stem Cells for Steroid-Refractory Acute Graft-Versus-Host Disease: A Phase I/II Study. Int J Hematol (2013) 98(2):206-13. doi: 10.1007/s12185-013-1399-4

42. Resnick IB, Barkats C, Shapira MY, Stepensky P, Bloom AI, Shimoni A, et al. Treatment of Severe Steroid Resistant Acute GVHD With Mesenchymal Stromal Cells (MSC). Am J Blood Res (2013) 3(3):225-38.

43. Introna M, Lucchini G, Dander E, Galimberti S, Rovelli A, Balduzzi A, et al. Treatment of Graft Versus Host Disease With Mesenchymal Stromal Cells: A Phase I Study on 40 Adult and Pediatric Patients. Biol Blood Marrow Transplant (2014) 20(3):375-81. doi: 10.1016/j.bbmt.2013.11.033

44. Sánchez-Guijo F, Caballero-Velázquez T, López-Villar O, Redondo A, Parody R, Martínez C, et al. Sequential Third-Party Mesenchymal Stromal Cell Therapy for Refractory Acute Graft-Versus-Host Disease. Biol Blood Marrow Transplant (2014) 20(10):1580-5. doi: 10.1016/j.bbmt.2014.06.015

45. von Dalowski F, Kramer M, Wermke M, Wehner R, Röllig C, Alakel N, et al. Mesenchymal Stromal Cells for Treatment of Acute Steroid-Refractory Graft Versus Host Disease: Clinical Responses and Long-Term Outcome. Stem Cells (2016) 34(2):357-66. doi: 10.1002/stem.2224

46. Kuçi Z, Bönig H, Kreyenberg H, Bunos M, Jauch A, Janssen JW, et al. Mesenchymal Stromal Cells From Pooled Mononuclear Cells of Multiple Bone Marrow Donors as Rescue Therapy in Pediatric Severe SteroidRefractory Graft-Versus-Host Disease: A Multicenter Survey. Haematologica (2016) 101(8):985-94. doi: 10.3324/haematol.2015.140368

47. Muroi K, Miyamura K, Okada M, Yamashita T, Murata M, Ishikawa T, et al. Bone Marrow-Derived Mesenchymal Stem Cells (JR-031) for SteroidRefractory Grade III or IV Acute Graft-Versus-Host Disease: A Phase II/III Study. Int J Hematol (2016) 103(2):243-50. doi: 10.1007/s12185-015-1915-9

48. Erbey F, Atay D, Akcay A, Ovali E, Ozturk G. Mesenchymal Stem Cell Treatment for Steroid Refractory Graft-Versus-Host Disease in Children: A Pilot and First Study From Turkey. Stem Cells Int (2016) 2016:1641402. doi: $10.1155 / 2016 / 1641402$

49. Dotoli GM, De Santis GC, Orellana MD, de Lima Prata K, Caruso SR, Fernandes TR, et al. Mesenchymal Stromal Cell Infusion to Treat Steroid-Refractory Acute GvHD III/IV After Hematopoietic Stem Cell Transplantation. Bone Marrow Transplant (2017) 52(6):859-62. doi: 10.1038/bmt.2017.35

50. Salmenniemi U, Itälä-Remes M, Nystedt J, Putkonen M, Niittyvuopio R, Vettenranta K, et al. Good Responses But High TRM in Adult Patients After MSC Therapy for GvHD. Bone Marrow Transplant (2017) 52(4):606-8. doi: 10.1038/bmt.2016.317

51. Ringden O, Baygan A, Remberger M, Gustafsson B, Winiarski J, Khoein B, et al. Placenta-Derived Decidua Stromal Cells for Treatment of Severe Acute Graft-Versus-Host Disease. Stem Cells Transl Med (2018) 7(4):325-31. doi: $10.1002 / \mathrm{sctm} .17-0167$

52. Bader P, Kuçi Z, Bakhtiar S, Basu O, Bug G, Dennis M, et al. Effective Treatment of Steroid and Therapy-Refractory Acute Graft-Versus-Host Disease With a Novel Mesenchymal Stromal Cell Product (MSC-FFM). Bone Marrow Transplant (2018) 53(7):852-62. doi: 10.1038/s41409-0180102-z

53. Galleu A, Milojkovic D, Deplano S, Szydlo R, Loaiza S, Wynn R, et al. Mesenchymal Stromal Cells for Acute Graft-Versus-Host Disease: Response at 1 Week Predicts Probability of Survival. Br J Haematol (2019) 185(1):89-92. doi: 10.1111/bjh.15749

54. Bonig H, Kuçi Z, Kuçi S, Bakhtiar S, Basu O, Bug G, et al. Children and Adults With Refractory Acute Graft-Versus-Host Disease Respond to Treatment With the Mesenchymal Stromal Cell Preparation "MSC-FFM"-Outcome Report of 92 Patients. Cells (2019) 8(12):1577. doi: 10.3390/cells8121577 
55. Kurtzberg J, Abdel-Azim H, Carpenter P, Chaudhury S, Horn B, Mahadeo K, et al. A Phase 3, Single-Arm, Prospective Study of Remestemcel-L, Ex Vivo Culture-Expanded Adult Human Mesenchymal Stromal Cells for the Treatment of Pediatric Patients Who Failed to Respond to Steroid Treatment for Acute Graft-Versus-Host Disease. Biol Blood Marrow Transplant (2020) 26(5):845-54. doi: 10.1016/j.bbmt.2020.01.018

56. Kurtzberg J, Prockop S, Chaudhury S, Horn B, Nemecek E, Prasad V, et al. Study 275: Updated Expanded Access Program for Remestemcel-L in SteroidRefractory Acute Graft-Versus-Host Disease in Children. Biol Blood Marrow Transplant (2020) 26(5):855-64. doi: 10.1016/j.bbmt.2020.01.026

57. van der Wagen LE, Miranda-Bedate A, Janssen A, Fernando F, Appukudige N, van Dooremalen S, et al. Efficacy of MSC for Steroid-Refractory Acute GVHD Associates With MSC Donor Age and a Defined Molecular Profile. Bone Marrow Transplant (2020) 55(11):2188-92. doi: 10.1038/s41409-020-0910-9

58. Zhao K, Lou R, Huang F, Peng Y, Jiang Z, Huang K, et al. Immunomodulation Effects of Mesenchymal Stromal Cells on Acute Graft-Versus-Host Disease After Hematopoietic Stem Cell Transplantation. Biol Blood Marrow Transplant (2015) 21(1):97-104. doi: 10.1016/j.bbmt.2014.09.030

59. Forslöw U, Blennow O, LeBlanc K, Ringdén O, Gustafsson B, Mattsson J, et al. Treatment With Mesenchymal Stromal Cells Is a Risk Factor for PneumoniaRelated Death After Allogeneic Hematopoietic Stem Cell Transplantation. Eur J Haematol (2012) 89(3):220-7. doi: 10.1111/j.1600-0609.2012.01824.x

60. Zhou H, Guo M, Bian C, Sun Z, Yang Z, Zeng Y, et al. Efficacy of Bone Marrow-Derived Mesenchymal Stem Cells in the Treatment of Sclerodermatous Chronic Graft-Versus-Host Disease: Clinical Report. Biol Blood Marrow Transplant (2010) 16(3):403-12. doi: 10.1016/j.bbmt.2009. 11.006

61. Weng JY, Du X, Geng SX, Peng YW, Wang Z, Lu ZS, et al. Mesenchymal Stem Cell as Salvage Treatment for Refractory Chronic GVHD. Bone Marrow Transplant (2010) 45(12):1732-40. doi: 10.1038/bmt.2010.195

62. Pérez-Simon JA, López-Villar O, Andreu EJ, Rifón J, Muntion S, Diez Campelo M, et al. Mesenchymal Stem Cells Expanded In Vitro With Human Serum for the Treatment of Acute and Chronic Graft-Versus-Host Disease: Results of a Phase I/II Clinical Trial. Haematologica (2011) 96 (7):1072-6. doi: 10.3324/haematol.2010.038356

63. Peng Y, Chen X, Liu Q, Zhang X, Huang K, Liu L, et al. Mesenchymal Stromal Cells Infusions Improve Refractory Chronic Graft Versus Host Disease Through an Increase of CD5+ Regulatory B Cells Producing Interleukin 10. Leukemia (2015) 29(3):636-46. doi: 10.1038/leu.2014.225

64. Boberg E, von Bahr L, Afram G, Lindström C, Ljungman P, Heldring N, et al. Treatment of Chronic GvHD With Mesenchymal Stromal Cells Induces Durable Responses: A Phase II Study. Stem Cells Transl Med (2020) 9 (10):1190-202. doi: 10.1002/sctm.20-0099

65. van Hoeven V, Munneke JM, Cornelissen AS, Omar SZ, Spruit MJ, Kleijer M, et al. Mesenchymal Stromal Cells Stimulate the Proliferation and IL-22 Production of Group 3 Innate Lymphoid Cells. J Immunol (2018) 201 (4):1165-73. doi: 10.4049/jimmunol.1700901

66. Lindemans CA, Calafiore M, Mertelsmann AM, O'Connor MH, Dudakov JA, Jenq RR, et al. Interleukin-22 Promotes Intestinal-Stem-Cell-Mediated Epithelial Regeneration. Nature (2015) 528(7583):560-4. doi: 10.1038/ nature 16460

67. Galleu A, Riffo-Vasquez Y, Trento C, Lomas C, Dolcetti L, Cheung TS, et al. Apoptosis in Mesenchymal Stromal Cells Induces In Vivo Recipient-Mediated Immunomodulation. Sci Transl Med (2017) 9(416):eaam7828. doi: 10.1126/ scitranslmed.aam7828

68. Rizk M, Monaghan M, Shorr R, Kekre N, Bredeson CN, Allan DS. Heterogeneity in Studies of Mesenchymal Stromal Cells to Treat or Prevent Graft-Versus-Host Disease: A Scoping Review of the Evidence. Biol Blood Marrow Transplant (2016) 22(8):1416-23. doi: 10.1016/j.bbmt.2016.04.010
69. Murata M, Ikegame K, Morishita Y, Ogawa H, Kaida K, Nakamae H, et al. Low-Dose Thymoglobulin as Second-Line Treatment for Steroid-Resistant Acute GvHD: An Analysis of the JSHCT. Bone Marrow Transplant (2017) 52 (2):252-7. doi: 10.1038/bmt.2016.247

70. Rowlings PA, Przepiorka D, Klein JP, Gale RP, Passweg JR, Henslee-Downey PJ, et al. IBMTR Severity Index for Grading Acute Graft-Versus-Host Disease: Retrospective Comparison With Glucksberg Grade. Br J Haematol (1997) 97 (4):855-64. doi: 10.1046/j.1365-2141.1997.1112925.x

71. MacMillan ML, Robin M, Harris AC, DeFor TE, Martin PJ, Alousi A, et al. A Refined Risk Score for Acute Graft-Versus-Host Disease That Predicts Response to Initial Therapy, Survival, and Transplant-Related Mortality. Biol Blood Marrow Transplant (2015) 21(4):761-7. doi: 10.1016/j.bbmt.2015.01.001

72. Jagasia M, Perales MA, Schroeder MA, Ali H, Shah NN, Chen YB, et al. Ruxolitinib for the Treatment of Steroid-Refractory Acute GVHD (REACH1) A Multicenter, Open-Label Phase 2 Trial. Blood (2020) 135(20):1739-49. doi: 10.1182/blood.2020004823

73. Khoury H, Kashyap A, Adkins DR, Brown RA, Miller G, Vij R, et al. Treatment of Steroid-Resistant Acute Graft-Versus-Host Disease With AntiThymocyte Globulin. Bone Marrow Transplant (2001) 27(10):1059-64. doi: 10.1038/sj.bmt.1703032

74. Couriel D, Saliba R, Hicks K, Ippoliti C, de Lima M, Hosing C, et al. Tumor Necrosis Factor-Alpha Blockade for the Treatment of Acute GVHD. Blood (2004) 104(3):649-54. doi: 10.1182/blood-2003-12-4241

75. Teshima T, Reddy P, Zeiser R. Acute Graft-Versus-Host Disease: Novel Biological Insights. Biol Blood Marrow Transplant (2016) 22(1):11-6. doi: 10.1016/j.bbmt.2015.10.001

76. Mohty M. Mechanisms of Action of Antithymocyte Globulin: T-Cell Depletion and Beyond. Leukemia (2007) 21(7):1387-94. doi: 10.1038/ sj.leu. 2404683

77. Bacigalupo A. Antilymphocyte/thymocyte Globulin for Graft Versus Host Disease Prophylaxis: Efficacy and Side Effects. Bone Marrow Transplant (2005) 35(3):225-31. doi: 10.1038/sj.bmt.1704758

78. Kanda J, Brazauskas R, Hu ZH, Kuwatsuka Y, Nagafuji K, Kanamori H, et al. Graft-Versus-Host Disease After HLA-Matched Sibling Bone Marrow or Peripheral Blood Stem Cell Transplantation: Comparison of North American Caucasian and Japanese Populations. Biol Blood Marrow Transplant (2016) 22(4):744-51. doi: 10.1016/j.bbmt.2015.12.027

Conflict of Interest: MM has received honoraria from Kyowa Kirin, Sumitomo Dainippon Pharma, FUJIFILM, Toyama Chemical, Novartis Pharma, MSD, JCR Pharmaceuticals, Astellas Pharma, Miyarisan Pharmaceutical, Asahi Kasei Pharma, GlaxoSmithKline, Celgene and Otsuka Pharmaceutical. TT has received grants from Kyowa Kirin, Chugai, Sanofi, Astellas, TEIJIN PHARMA, Fuji Pharma and NIPPON SHINYAKU; personal fees from Novartis, Merck, Kyowa Kirin, Takeda, Pfizer and Bristol-Myers Squibb; and non-financial support from Janssen and Novartis.

Publisher's Note: All claims expressed in this article are solely those of the authors and do not necessarily represent those of their affiliated organizations, or those of the publisher, the editors and the reviewers. Any product that may be evaluated in this article, or claim that may be made by its manufacturer, is not guaranteed or endorsed by the publisher.

Copyright (c) 2021 Murata and Teshima. This is an open-access article distributed under the terms of the Creative Commons Attribution License (CC BY). The use, distribution or reproduction in other forums is permitted, provided the original author(s) and the copyright owner(s) are credited and that the original publication in this journal is cited, in accordance with accepted academic practice. No use, distribution or reproduction is permitted which does not comply with these terms. 